\title{
Applying GIS Technologies for Mapping Natural and Anthropogenic Transformed Soils in the Southern Forest-Steppe of the Republic of Bashkortostan
}

\author{
Marat Ishbulatov, Ilnur Miftakhov, Zila Churagulova, Radik Mindibayev, Alexander Komissarov \\ Federal State Budgetary Educational Establishment of Higher Education "Bashkir State Agrarian University", \\ Ufa, Russia
}

\begin{abstract}
Soil is a core element of the biosphere, and the soil cover is exposed to major processes that take place within this system. Therefore, it is very important to understand the results of soil research from the perspective of current global and local environmental problems. With the advent of new methods of spatial analysis and techniques for obtaining remote sensing data, geoinformation technologies offer great opportunities for analyzing the natural and ecological state of the region. Therefore, geoinformation analysis of the state of natural and anthropogenic transformed soils is an essential tool for their studying, forecasting the development of the natural environment, and working out the ways of rational farming. As forest territories have a beneficial effect on the natural and climatic situation in general, and vice versa, environmental degradation on agricultural lands will result in worsening the situation on forest lands, it is necessary to consider forest and agricultural areas in close integration with GIS technologies. It should be done to improve the overall natural environmental conditions. The study used soil survey data conducted in 2017-2019. Field and office studies were conducted: samples were taken in the field to determine the agrochemical parameters of the soil, and the data obtained were analyzed using mathematical and statistical methods. Digital cartographic materials were created using geoinformation technologies. The basis for a comprehensive natural and environmental assessment of forest and agricultural areas using geoinformation systems was laid. The studies conducted to identify changes in natural and anthropogenic transformed soils have shown that the contours of soil varieties have changed. In many cases, there is a deterioration in soil properties. The number of fertile chernozem has decreased. In areas with low crop cultivation, there are signs of a decrease in the humus horizon and the development of erosion processes. As a result of the conducted research, a single digital soil and geographical database for forest and agricultural territories were created. The developed methodology and algorithm for creating a database and digital cartographic basis using geoinformation technologies in environmental studies can be recommended as a base for similar studies both in the Republic of Bashkortostan and in other regions
\end{abstract}

\section{Keywords}

Environmental conditions, forest and agricultural territories, GIS technologies, soil mapping.

Ishbulatov, M., Miftakhov, I., Churagulova, Z., Mindibayev, R. and Komissarov, A. (2020) “Applying GIS Technologies for Mapping Natural and Anthropogenic Transformed Soils in the Southern Forest-Steppe of the Republic of Bashkortostan", AGRIS on-line Papers in Economics and Informatics, Vol. 12, No. 4, pp. 29-45. ISSN 1804-1930. DOI 10.7160/aol.2020.120403.

\section{Introduction}

The leading role is assigned to the effective use of land resources, regular and systematic improvement of soil fertility to solve the food problem successfully. The development of modern geoinformation technologies allows analyzing the soil state and visualizing it in the form of the map that reflects each assessment stage, as well as the synthesis of the results obtained.
The end of the 20th century and the beginning of the $21^{\text {st }}$ century is an unprecedented era of low food prices for Western industrialized countries. The main challenges facing humanity today are overpopulation, food shortage, environmental pollution, deforestation, and natural disasters. According to the reports of the UN Food and Agriculture Organization, deforestation continues worldwide at a rapid pace. Every year, $15 \mathrm{mln}$ ha of forest is lost, while only 5 ha grows. 
According to scientists, the planet overpopulation can lead to global conflicts due to food shortages (FAO, 2011). Currently, the desertification processes in the South of Russia affect about $60 \mathrm{mln}$ ha of farmland. One of the most significant desertification factors in this area is agricultural land degradation and the degradation of natural pastures in particular. In the South of the European part, the chernozem soils of Kalmykia and the flat areas of Dagestan have been particularly affected. Currently, these regions are characterized by the most intense manifestation of anthropogenic desertification, which covers more than 70\% of the territory. In Astrakhan, Volgograd, Saratov, Samara regions, and Tatarstan, up to $50 \%$ of the entire territory is affected by desertification (Pendzhiev, 2013). The geographic decision support system is a very complex area since a considerable amount of spatial data is accumulated in various fields of application, from remote sensing to GIS, computer mapping, environmental assessment, and planning. GIS will provide an opportunity to create maps, integrate information, visualize scenarios, solve complex problems, introduce powerful ideas, and develop practical solutions. Using the GIS application, you can open digital maps on your computer, create new spatial information to add to the map, create printed maps customized to their needs, and perform the spatial analysis. Spatial database management systems aim to make spatial data management easier and more natural for preparing maps for users or applications such as urban planning, utilities, transportation, and remote sensing (Manjula et al., 2011).

Soil is a natural body consisting of layers (soil horizons) resulting from the interaction of climate, topography, organisms, source material (underlying geological rock), and time (Lucà et al., 2018). Accurate soil data are needed to develop reliable, high-resolution soil maps for the hydrological analysis, environmental protection, agriculture, and forest management. The information elements required for the soil characterization obtained from the sources with different spatial resolutions can be easily stored and managed within the framework of a geographic information system (GIS). Digital soil mapping (DSM) allows analyzing the relationship between soil properties and auxiliary data (for example, cartometric attributes and remote/proximal sensing data) using several pedometric techniques. The research is an attempt to use GIS in soil science at various spatial scales by describing the growing availability of auxiliary data for soil characterization; illustrating the primary relationships between soil properties and digital terrain models - derived topographic objects; generalizing spatial and nonspatial pedometric techniques for the analysis and modeling of soil properties; and illustrating some GIS applications in soil science, as well as using the obtained data in land use planning and soil protection.

Due to the wide variety of soil types and the complexity of soil and environmental conditions in the southern forest-steppe of the Republic of Bashkortostan, specific zonal and locally differentiated and scientifically based approaches to maintaining and improving the soil fertility are required. These conditions are also imposed by economic activity, which has a significant impact on the vegetation and soil cover. Deforestation, plowing vast land areas, unregulated livestock grazing leads to the destruction, reduction, and thinning of vegetation cover, all this has a negative impact on the soil condition of the region. For example, according to the statistical reporting, in 2019, the results of satellite monitoring of the forests in the Republic of Bashkortostan revealed 20 violations of illegal deforestation ith a total volume of about 3,500 $\mathrm{m} 3$ of wood.

The deterioration of the general environmental conditions due to the energy and mass exchange imbalance in the "soil-plant-environment" system and the observed weakening of the ecological functions of soil fertility, decrease in the accumulative horizon thickness, negative humus balance, genetically low nitrogen and phosphorus content, destruction, and preconsolidation of the arable soil layer, accompanied by a marked decrease in the air and heat transfer and biological activity of soils are characteristic features of the current state of agricultural land (Zaripova et al., 2009).

Agricultural production is a key force affecting soil processes and functions. Due to biophysical constraints, as well as rapid structural and technological development, new methods of agricultural production management appear that have a significant negative impact on soil processes and functions (Techen et al., 2020). This makes it difficult to assess the potential of land resources to meet the growing demand for food and non-food products. From the point of view of rational soil use, sustainable intensification means that the volume of products received from the given territory increases while maintaining soil quality indicators such as humus horizon, humus and nutrient content, 
environment $\mathrm{pH}$, and salinity. The research aims to study the impact of new land management methods on soil processes. There are four categories of land management methods: scientifically-based farming system, crop rotation design based on soil and topography, use of reasonable mechanisms for soil treatment, and soil pollution. At the same time, they study the efficiency of nutrient use compared to traditional crop cultivation systems, the state of the soil-rhizosphere microbiome and its interaction with crops in crop rotation, the effect of soil compaction on soil-plantatmosphere interaction, and the ecotoxicity of plastics, pharmaceuticals, and other pollutants that enter the soil. There is a need for an interdisciplinary, systematic approach to soil science and research related to process modeling, data management, and assessment of soil stability under various management methods. The identification of soil science research problems from the point of view of agricultural management contributes to the establishment of cooperation between various scientific disciplines in the field of sustainable agricultural production.

Our planet is experiencing one of the fastest climate changes in the history of the Earth. The current change is particularly significant, as it is most likely a consequence of human activity since the 19th century (Jia et al., 2019). The digital Earth model, which includes satellites in near-Earth orbit, ground-based observations, and other data collection, analysis, and visualization technologies, has allowed scientists to see our climate and its impact at the regional and global levels. The Digital Earth platform provides valuable information about the atmosphere, biosphere, hydrosphere, and cryosphere to understand the past and present of the Earth. It also supports Earth system models for climate prediction and forecasting. Case studies where the Digital Earth model is used in the climate change research, such as climate sensing, information, and simulation systems for global environmental change, and synchronous satellite, aerial, and ground observation experiments that provide extensive and abundant data sets. Mapping climate extremes and impacts increase the preparedness for climate change risks and provide reliable data for management decisions. However, Digital Earth faces challenges in coordinating and integrating multi-source data, which requires an international partnership between governments and other intergovernmental organizations to develop open data policies and practices.

With climate change, the problems of agricultural production and food security have become particularly acute in the twenty-first century. For example, the Himalayan country of Bhutan is an agricultural country where about $57 \%$ of the population depends on agriculture. However, farming is constrained by mountainous terrain and rapid changes in environmental variability. The country is already experiencing some of the effects of climate change, such as crop loss due to unusual outbreaks of diseases and pests, erratic rains, hurricanes, hail storms, droughts, flash floods and landslides annually (Chhogyel and Kumar, 2018).

One of the most serious problems in sub-Saharan Africa is the need to increase crop production to meet the increasing demand of the growing population. To this end, knowledge of soil resources and their agricultural potential is essential for determining proper and appropriate land use and land management (Nguemzei et al., 2020). Studies of soil fertility in the Tombel region were conducted to study the current state of soil resources and monitor the impact of physical and chemical properties on soil fertility. Analyses on various indicators revealed a direct influence of the physical and chemical soil properties and other derived parameters of soil fertility on the main factors of plant growth and development, such as the ability to retain water, root development, soil aeration, nutrient existence and availability, and cation balance. Based on the physical and chemical soil properties, fertility parameters, and the soil quality index, four classes of soil fertility were determined in this area: 1) very good fertile soil $\left.\left(66 \mathrm{~km}^{2}\right), 2\right)$ good fertile soil $\left(506 \mathrm{~km}^{2}\right)$, 3) fairly good fertile soil $\left(787 \mathrm{~km}^{2}\right)$, 4) low-fertility soil $\left(375 \mathrm{~km}^{2}\right)$. The main indicators that control the soil quality in the Tombel area, obtained on the basis of ANOVA and PCA analysis, are $\mathrm{Ca}, \mathrm{Mg}$, water $\mathrm{pH}$, organic matter, total nitrogen, and zinc. Four out of seven indicators $(\mathrm{Ca}, \mathrm{pH}$, $\mathrm{OM}, \mathrm{P})$ were also identified as important indicators for assessing the fertility state of various soil groups in the Tombel area.

Economic activities, including logging, coal mining and other types of work, are the most important disturbing activities that affect the ecological functioning and conservation of forest biodiversity, and also adversely affect the agriculture (Kimaro and Lulandala, 2013). In addition, it is noted that the values of species diversity, composition, and regeneration potential within undisturbed forest areas differ significantly from those in severely disturbed areas. These observations 
confirm that current human activity has already led to a deterioration in the quantity and quality of useful plants, an increased impact of species diversification on the forest ecosystem, and possibly a negative impact on the livelihoods of local communities.

Human activity leads to changes in the global environment, sometimes with serious consequences for our future lives (Várallyay, 2010). Changes in the gas composition of the atmosphere, partly due to the emission of $\mathrm{CO} 2$ and "greenhouse gases", can lead to an increase in temperature with high spatial and temporal variability, to changes in global circulation processes, and a serious precipitation redistribution, an increase in aridity in some areas. These changes have a sensitive effect on ecosystems (natural vegetation and land use structure) and significant changes in soil formation and degradation processes, as well as in soil properties and functions.

All indicators of the forest influence on climate, hydrology, soil formation, sanitary and hygienic properties, and recreational suitability of its growing area can be safely attributed to the ecological potential. It is established that the landscape method is subjective, it does not give an idea of the recreational suitability, does not allow for mathematical data processing, but can serve as a basis for preliminary object characteristics (Sultanovaet al., 2018).

The ecological state in India is significantly deteriorating, and soils are formed through the diverse interaction of several forces, including climate, terrain, parent species, and organisms. It takes thousands of years for soil to form, and most soils continue to transform after changes in some soil-forming factors, in particular, climate and vegetation over the past few decades. Climate is one of the most important factors affecting soil formation, which is essential for their development, use, and management in terms of soil structure, stability, moisture retention of the topsoil, nutrient availability, and erosion. Various authors predict that the expected changes in temperature, precipitation, and evaporation will cause significant changes in both organic matter turnover and $\mathrm{CO}^{2}$ dynamics (Karmakar et al., 2016; Uskov and Bulat, 2014).

Soil erosion is a serious problem that humanity faces today, as it continually worsens the quality and standard of living around the world. As a hilly country with undulating terrain with steeper slopes accompanied by heavy rainfall, Nepal is prone to natural disasters, including soil erosion (Chalise et al., 2018). In the work of Chalise and colleagues, an attempt was made to model the soil erosion rate in the Aringale Khola catchment area of the middle hills of Nepal using the methods of the geoinformation system (GIS) and the revised universal soil loss equation (RUSLE). RUSLE was used in ArcGIS, taking precipitation - Runoff (R), soil erodibility (K), topography (LS), crop management $(\mathrm{C})$, and other factors as primary input data. In total, nine classes of soil erosion were observed, the soil erosion rate ranged from 0.03 to $100.33 \mathrm{t} / \mathrm{ha} /$ year, with an average level of soil erosion of $11.17 \mathrm{t} / \mathrm{ha} /$ year. GIS analysis showed that $36.93 \%$ (1256.28 ha) of the total catchment area is highly eroded, while the remaining $63.07 \%$ ( $2145.56 \mathrm{ha}$ ) is less eroded. Much of the catchment area, especially areas with higher elevations and steep slopes, is degraded and needs urgent soil conservation measures. This study is the first attempt to model the spread of soil erosion in the Aringale Khola catchment and can be used to predict soil erosion in similar catchments in the middle hills of Nepal.

Soil cover is an important element in the study of the relationship between human activity and the environment. The monitoring of soil indicators is necessary to identify deviations to preserve the maintained environment (Kayet and Pathak, 2015). Remote sensing is a tool for monitoring land use and land cover. The studies were conducted to assess the state of land use and changes in the soil and vegetation cover at the beginning of 1992, 2005, and 2014 on the territory of the Saranda forest. ArcMap GIS software was used to create and analyze thematic maps. This software made it possible to identify land-use features, taking into account the soil and vegetation cover, to preserve a stable environment while increasing productivity. The study revealed a rapid expansion of the builtup (mining) territory and an increase in agricultural land area with a decrease in the area of dense forests and water bodies.

Deforestation and the conversion of natural pasture land to agricultural land are two major threats to soil and water conservation, causing erosion and possibly desertification. The aim of the research in the Tzicatlacoyan area was to assess soil erosion using the universal equation of soil loss through geographical information systems (GIS) (López-García et al., 2019). The results showed that Tzicatlacoyan faces the risk of soil erosion at an average annual rate of $117.18 \mathrm{t} / \mathrm{ha} /$ year, due 
to natural factors and anthropogenic activities, such as the use of agricultural land without erosion control measures. Four classes of soil erosion risk were identified depending on the erosion rate (a) in $\mathrm{t} / \mathrm{ha}$ /year: extreme risk $(114 \geq \mathrm{a} \leq 234.36)$, severe risk $(59 \geq \mathrm{A}<114)$, moderate risk $(23 \geq \mathrm{a}<59)$, and low risk. Most of the area $\left(180.96 \mathrm{~km}^{2}, 64.83 \%\right)$ was characterized by a low risk of erosion, while a small part $\left(11.64 \mathrm{~km}^{2}\right.$, $4.17 \%$ ) of the study area was characterized by a high risk. The results showed that on $13.33 \%$ of the Tzicatlacoyan territory, the current values of soil losses exceed the permissible ones. Soil erosion assessment using a GIS model can allow land users to make more effective decisions about land use while preserving the soil and the entire ecosystem.

To identify changes in soil salinity and their impact on the vegetation cover is necessary to understand the relationships between these changes in the vegetation cover. This study, aimed at determining the changes in soil salinity and vegetation cover over the past 28 years, was conducted in the Al-Ahsa Oasis. Landsat timeseries data for 1985, 2000, and 2013 were used to obtain images with vegetation index (NDVI) and soil salinity index (SI), which were then used in image differentiation to identify the vegetation and salinity changes-no changes over two periods. Soil salinization in 2000-2013 was significantly higher than in 1985-2000, and the vegetation cover decreased to $6.31 \%$ over the same period (Allbed et al., 2018).

In Turkey, the information about the current environment as a result of anthropogenic impacts on nature is recorded in an electronic environment, and an anthropogenic biome map has been created using the ArcGIS Desktop software. Analyzing the data obtained, we can say that over the past two centuries, the natural habitat has undergone considerable changes, the vegetation has deteriorated, and land degradation has increased due to the anthropogenic activity (Curebal et al., 2015).

The cadastre reflects the land plot boundaries of various owners. Changes in land legislation in recent years require considering and evaluating land by use type and soil varieties (Shapovalov et al., 2018). This method differs significantly from land accounting and valuation by land category and owner. As a result, the dynamics of cadastral division occurs in the form of an increase in the number of cadastral units - land plots, which is reflected in the public cadastral map. On the other hand, there is no real monitoring of land use, which leads to significant discrepancies with cadastral data and real changes in land use, which are detected during the retrospective monitoring of soils and vegetation cover. Real changes in land use structure are better correlated with soil cover than with cadastral division. The conflict resolution between the soil map compilation, cadastral division, and real land use can be achieved by introducing the soil and land cover concept. It is assumed that land cover maps will be created using retrospective monitoring technology.

Soil mapping and evaluation work allow compiling a graphical and descriptive database that is necessary for the inventory, classification, and evaluation of soil resources, which can be represented by an agricultural enterprise or administrative territory. The topsoil is studied in connection with natural and anthropogenic factors that determine its features and, accordingly, natural fertility, with various signs of favorability for the growth and development of agricultural or natural phytocenoses (Gosa and Mateoc-Sirb, 2014).

The use of geo-information systems (GIS) and remote sensing (RS) methods in soil mapping and classification provides significant advantages both in terms of time and cost and in terms of improving accuracy (Ramazanoglu et al., 2019). The study of Turkish scientists aimed to determine the conditions of soil formation, as well as to compile a classification of soils and their properties using GIS methods for the catchment of the Topchu stream in the Tarsus state, Mersin. Following the detailed soil geodetic and cartographic standards, a series of soils were outlined, soil samples were taken along the horizon, the physical and chemical soil characteristics were analyzed, and their classification was carried out. The change in topography, source material, land use, and surface properties of soils was determined using geoinformation methods.

In connection with the above, it should be noted that it is necessary to consider the soil and environmental situation in a particular region together on the territories of the forest fund and agricultural lands since the reduction of both forest and vegetation cover adversely affects the environmental situation as a whole.

The purpose of our study is to analyze the state 
of natural and anthropogenic transformed soils on the territory occupied by forests and crops, using geoinformation technologies for natural and environmental assessment and ensuring the sustainable development of natural and anthropogenic systems.

In this regard, the following tasks were set:

1. Create a single digital soil database for agricultural and state-owned land.

2. Develop a methodology for creating soil maps and their content using modern geoinformation technologies.

3. Conduct a comparative analysis of soil conditions for agricultural and state-owned land.

\section{Materials and methods}

The objects of the research were natural and anthropogenic transformed soils of the Dyurtyulinsky district of the Republic of Bashkortostan. The research program included the following: preparatory work, field soil mapping, laboratory analyses, office data processing.

Preparatory work consists of various, interrelated actions designed to ensure the quality and high efficiency of the entire study. During the preparatory period, the following materials have been selected and studied:

- aerial photography materials;

- previous soil survey materials;

- reports of soil and climate zoning of the survey territory;

- land assessment materials (soil and economic assessment);

- $\quad$ as well as literature and reference materials.

As a result of the analysis during the preparatory work, the primary materials of the soil survey and aerial photography data, when applied to MapInfo software, gave the result for compiling a preliminary layout of the updated soil map.

In field studies, a preliminary model of the soil map and aerial photographs were used as the planning and cartographic basis, aerial photographs are used to clarify the boundaries of individual soils and complexes. Fieldwork was carried out using the methods adopted in soil science, set out in the relevant guidelines (Ishbulatov et al., 2018a). Field studies were conducted on a scale of 1: 25000. The main sections, half-pits, and heeling-in were laid at the rate of one soil section per 5 hectares of the area. Soil samples at each point were selected based on the genetic horizons. Soil analyses were carried out according to generally accepted methods and Russian National Standards.

\section{Research design}

Analytical data processing was carried out using generally accepted variational and statistical methods based on the guidelines (Kalinin, 2015). The cartographic research method was previously widely used in the thematic map compilation. It included work on the collection and systematization of stock materials, as well as field expedition, laboratory, and office work. In the office period, cartographic work was performed using the terrain plasticity method, which allowed displaying the system and structural organization of delta surfaces on the map. Currently, this method has been replaced by geoinformation technologies that allow you to display all map layers on a single screen, and also accelerated the soil mapping process. The geographic information system (GIS) is a software and hardware complex based on digital maps with databases linked to them. GIS consists of two large blocks: electronic maps with databases and tools for ensuring GIS functioning. The use of GIS allows us to transfer the problem solution on creating a land assessment basis to a new qualitative basis (Ishbulatov et al., 2018b).

The essential GIS advantages:

- ability to automate the process of creating maps;

- ease of making changes, the ability to create systems for automatic adaptions to the database.

\section{Equipment}

The material was processed on a PC using standard computer programs such as "STATGRAPHICS Plus", "MS EXCEL", Mapinfo, Qgis.

\section{Agroclimatic}

Diurtiulinsky district refers to the Right-bank and partly to the Left-bank Pribelskiy hillside-plain district. It is characterized by the development of rocky and hilly plains with vast watersheds. The territory located on the watershed of the Belaya and Tanyp rivers, as well as in the valley of the Belaya River, has a high plowing rate $(62.96 \%)$ of the territory.

Diurtiulinsky district is located in the lower reaches 
of the Belaya River. There are two specially protected natural areas (SPNT) on its territory: the medicinal plant population in Dyurtyulinsky and Kangysh forestries. They, along with other SPNT, are recorded in the Register of specially protected territories of the Republic of Bashkortostan. There are forest-seed reserves and plantations of unique pinetum (Churagulova, 2003).

The study area of the Republic of Bashkortostan is located in a zone of warm-temperate semi-arid climate. The zone is characterized by sufficient, but not always stable moisture. According to Verkhne-Yarkeevo and Dyurtyuli weather stations, the climatic conditions are very variable over the seasons. Sometimes there are abnormally hot days in summer, the highest temperature is $+38^{\circ} \mathrm{C}$, for example, in 2010 , there were abnormally cold days in winter, the lowest temperature was $-46^{\circ} \mathrm{C}$, etc. The average annual air temperature here ranges from $2.3^{\circ} \mathrm{C}$ to $2.5^{\circ} \mathrm{C}$, the average monthly temperature of January is $-14.6^{\circ} \mathrm{C}$, of July from $+18.3^{\circ} \mathrm{C}$ to $19.1{ }^{\circ} \mathrm{C}$. The amount of annual precipitation is from $350-400$ to $450-500 \mathrm{~mm}$. The sum of temperatures for the same period is $2000-2200^{\circ} \mathrm{C}$.

The beginning of the frost-free period varies over the years from mid-May to the first decade of June; the end is more often noted before the first half of September. The length of the frost-free period is from 100-110 days in the Northern part to 130 or more - in high places. The snow cover height in the first half of winter is $15-20 \mathrm{~cm}$, in the second one $-30-40 \mathrm{~cm}$.

The area under study is characterized by a wide variety of vegetation. It includes many of the most diverse plants: large trees that raise their crowns many meters above the ground, relatively high shrubs, low shrubs, all kinds of herbs, including medicinal ones, and very small mosses and lichens. And each takes its specific place in the forest, plays a particular role in the forest life and life forms living in it. The forest is of exceptional importance not only as a source of wood production but mainly as a climate-forming factor that fulfills water conservation, soil, and wind protection. Forests that grow here are allocated to the area of dark coniferous-broad-leaved and pine forests.

\section{Data analysis}

As a result of the study, processing and analysis of the obtained qualitative and quantitative data were performed using GIS technologies. The results of the analysis can be presented as a map, values in a table, or chart-new information. It is necessary to decide what information should be mapped, how to group the values for the best data presentation.

In the process of result evaluation, the objectivity and necessity of the information obtained are determined to decide on repeating the analysis with other parameters or using another method. GIS makes it relatively easy to make the necessary changes and get a new result.

\section{Results and discussion}

From 1956 to 1997, on the instruction of the Ministry of Agriculture of the Bashkir Autonomous Soviet Socialist Republic, the employees of the Bashkir branch of the "Volgogiprozem" Institute conducted field soil surveys in all 54 districts of the Republic of Bashkortostan. From 2016 to the present day, Bashkir State Agrarian University, together with Volgoniigiprozem, are correcting the materials of the previous survey round, and electronic soil maps with layers in the geoinformation system are being created for the first time. At the moment, this work has been carried out in 33 districts. The purpose of the work was to study the soil state, identify changes that occurred after the last soil survey round, and compile a digital soil map. The soil survey is carried out in the municipal areas. If earlier these works were performed on the territory of individual agricultural enterprises, now the research is conducted in the context of rural settlements.

The following soil types and subtypes are identified on the territory of agricultural lands $(117,229.17 \mathrm{ha})$ and the former Durtyulinsky specialized seed forestry $(29,699 \mathrm{ha})$ (Table 1).

\begin{tabular}{|c|l|}
\hline & Name of soil types and subtypes \\
\hline 1 & Sod-weak-medium-strong podzolic, sod-podzolic gleyed \\
\hline 2 & Light gray, gray, dark gray texture-differentiated \\
\hline 3 & Clay-illuvial chernozem \\
\hline 4 & Wet-meadow \\
\hline 5 & Marshy, peaty-marshy \\
\hline 6 & Gully-beam complexes \\
\hline 7 & $\begin{array}{l}\text { Floodplain alluvial humus, dark-humus, dark humus } \\
\text { quasi-gley }\end{array}$ \\
\hline
\end{tabular}

Source: authors

Table 1: Prevailing soil types in Durtyulinsky district.

The soil cover of the territory, as shown by the data of continuous mapping, is represented 
by sod-podzolic, light-gray, gray cinnamonic, gray, dark-gray forest, black soil podzolized, meadowchernozemic, meadow-bog peat, alluvial floodplain granular, dark-grained sod-gleyed, and other soils, on the areas subject to anthropogenic impact - agro-soils with a homogeneous horizon.

The use of GIS technologies in soil mapping is primarily related to the digitization of map material. Several digitization techniques are used, depending on the available hardware and software products. The typical positions are scanning the topographic base and assigning coordinates to the resulting raster image, or decoding and digitizing orthophoto plans (halftones).
The result is a map in Mapinfo format, which is converted to a raster base with reference to the local coordinate system (MSK 02 zone 1). There are two ways to digitize a paper original: manual contour outlining on a registered topographic basis, on a recorded, scanned map, or automatically using vectorizers that digitize a paper-scanned contour grid.

Based on the received field survey materials and laboratory research results, the soil maps are corrected and digitized. The soil contour digitization is carried out on the basis of soil maps made in the period from 1992 to 1994 (Figure 1 and 2).

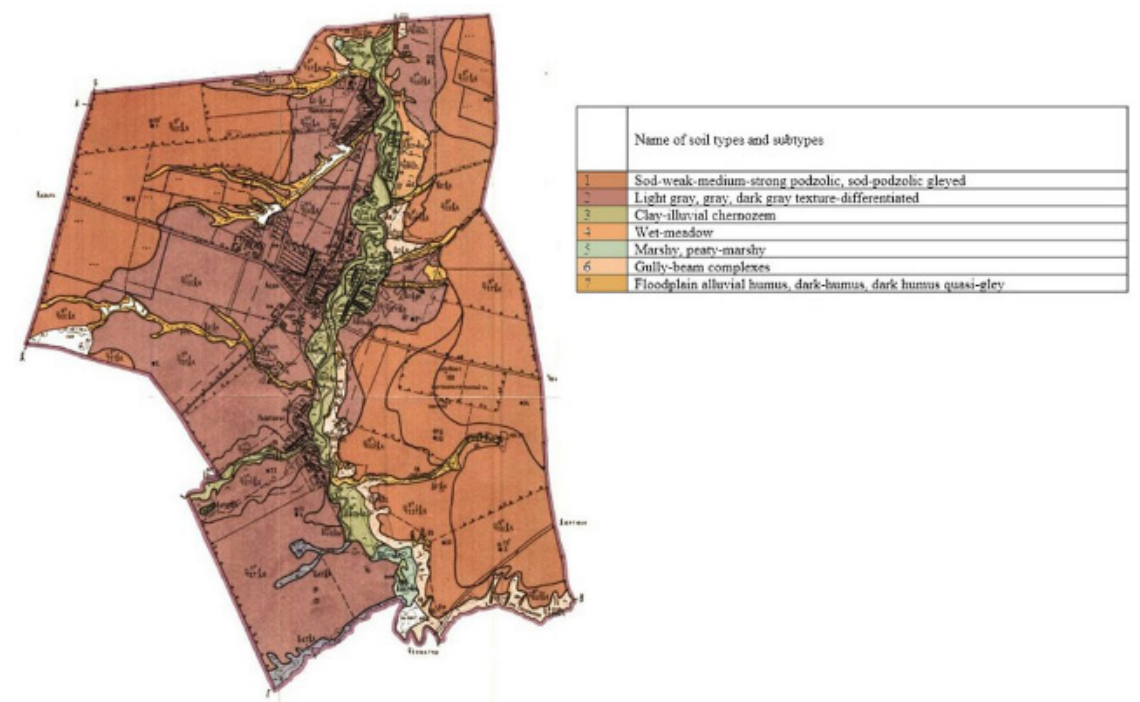

Source: authors

Figure 1: Soil map made according to the results of the 1992 soil survey within the boundaries of the Asyan collective farm of Dyurtyulinsky district RB.

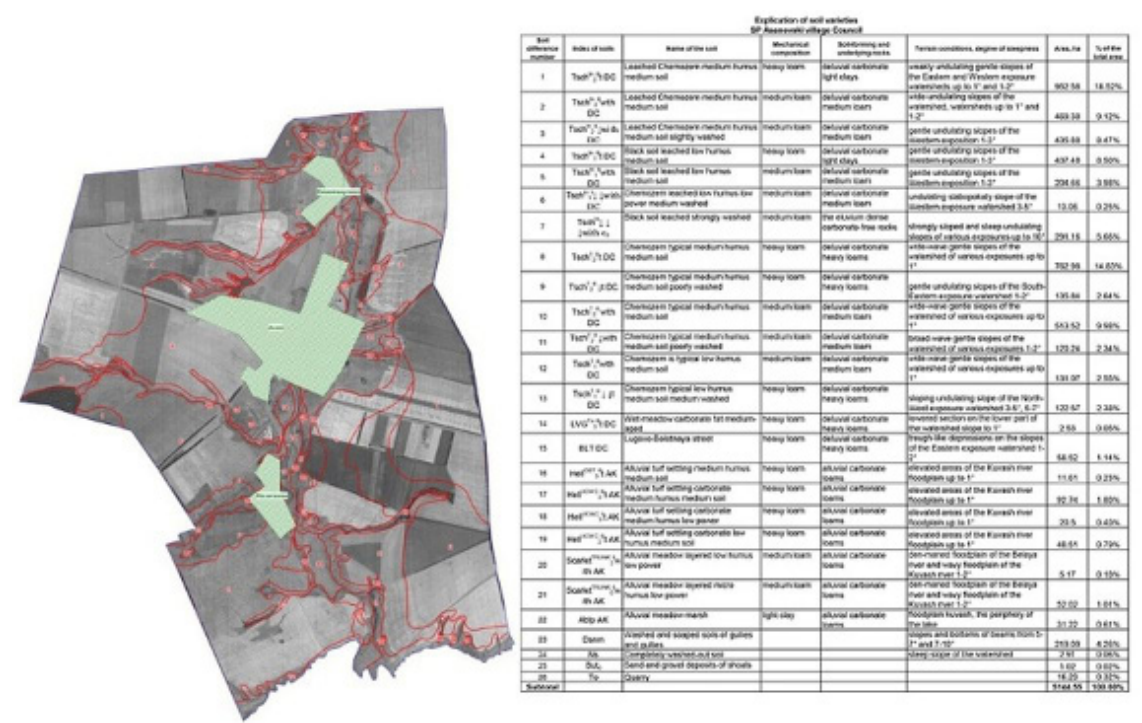

Source: authors

Figure 2: Orthophotoplan (halftone) flight 2007 for digitizing the planimetric base. 
When digitizing, it is necessary to restore the information that is partially lost or distorted due to the paper media wear, as well as scanning errors. In this regard, when digitizing maps, it is necessary to use the author's copies of soil maps. Next, digital soil maps are corrected. The elimination of inconsistency and disalignment is carried out by means of office clarification using cartographic documents and soil survey data from previous years.

Simultaneously with the land map, the soil map obtained as a result of the adjustment is digitized.

Cartographic models for analyzing the soil and ecological state and spatial information are combined with an electronic database that contains multicomponent characteristics of the study area.
This approach allows for land and environmental assessment to use its data in actions to take measures to improve the ecological situation. Creating a database in a GIS environment enables you to make adjustments about changes in various assessment subjects quickly. The soil database contains:

The results of this work are presented in the form of a complex electronic database.

Layer 1 - soil index, soil names, granulometric composition, soil-forming, and underlying bedrock, and area (Figure 3).

Layer 2 - humus content in the soil, nutrient planetism, $\mathrm{pH}$ value, thickness of the humus horizon (Figure 4).

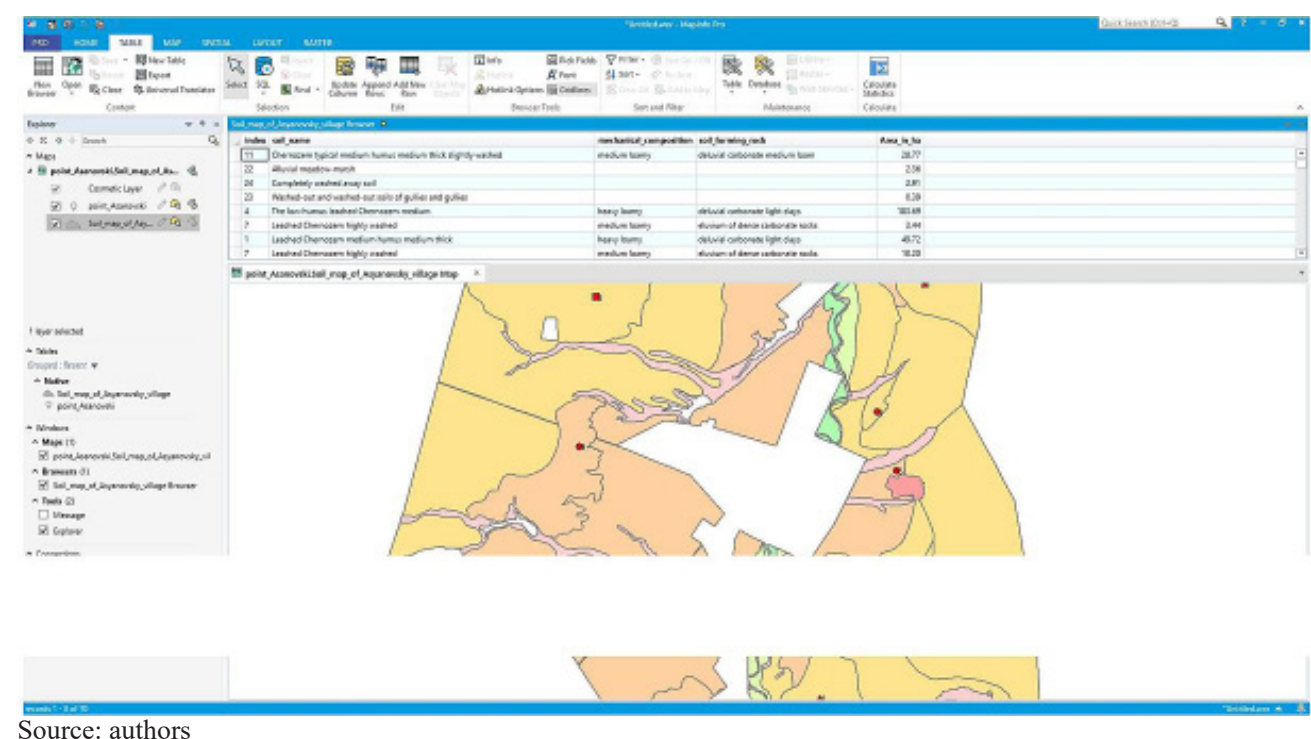

Source: authors

Figure 3: Electronic attribute database of the digital soil map, Layer 1.

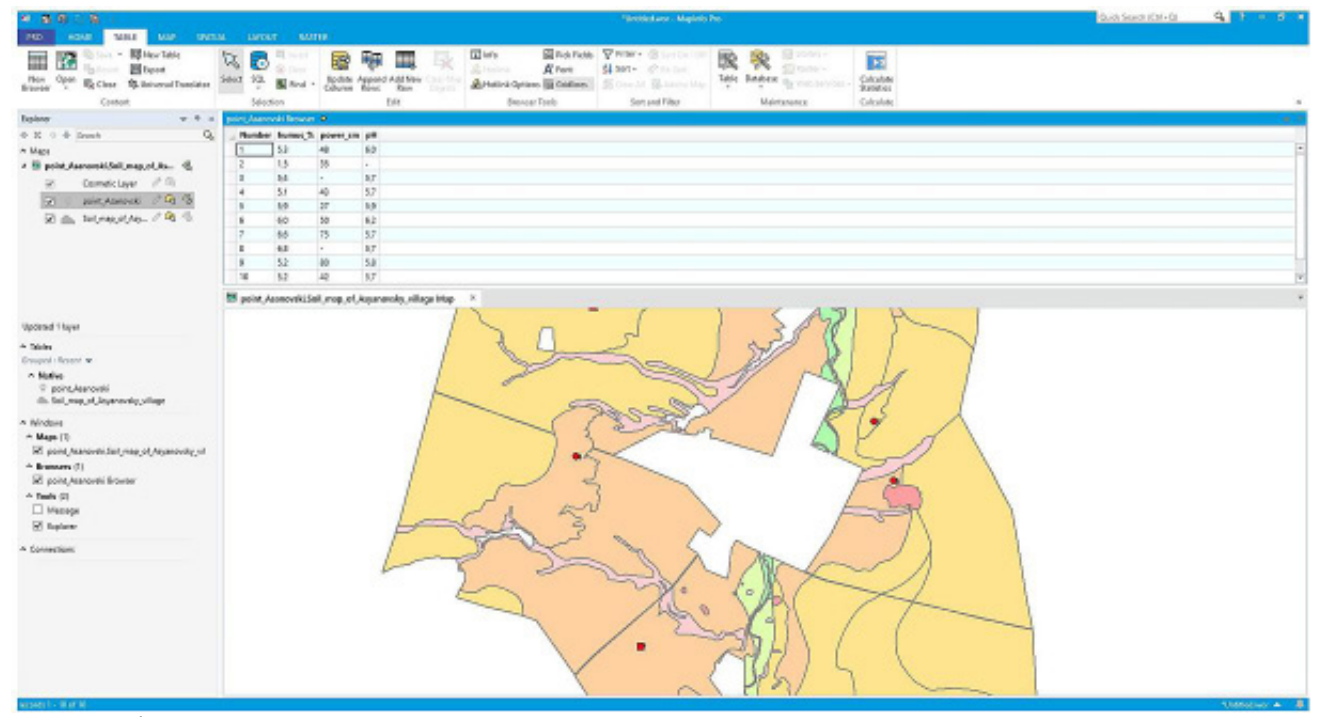

Source: authors

Figure 4: Electronic attribute database of the digital soil map, Layer 2. 
A raster base that is put in correspondence with the local coordinate system (MSK 02 zone 1) serves as a planimetric base to open the created layers and get the soil information. An electronic soil map containing information about forest and agricultural lands is shown in Figure 5.
Field soil surveys conducted on agricultural lands and state forest fund showed that there are no significant differences in soil varieties.

The following offers the data for a comparative analysis of adjacent sectors (Tables 2 and 3 ).

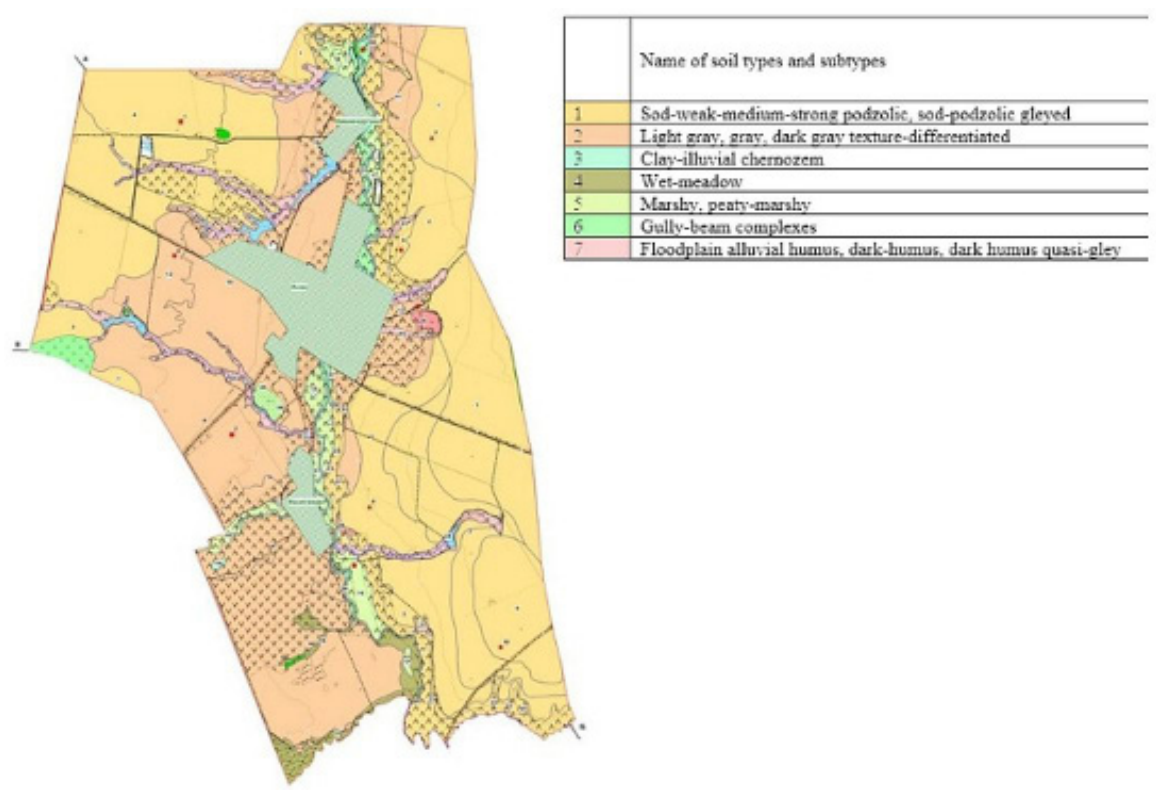

Source: authors

Figure 5: Soil map, based on the 2018 soil survey, as a result of the digitization and adjustment of the soil maps within the boundaries of the Asyanovsky village council of Dyurtyulinsky district RB.

\begin{tabular}{|c|c|c|c|c|c|c|c|c|c|c|}
\hline $\begin{array}{c}\text { Soil phase } \\
\text { number }\end{array}$ & $\begin{array}{c}\text { Main } \\
\text { section } \\
\text { number, } \\
\text { half- } \\
\text { pits, and } \\
\text { heeling-in }\end{array}$ & $\begin{array}{c}\text { Sampling } \\
\text { depth, cm }\end{array}$ & $\begin{array}{c}\text { Thickness } \\
\text { of the } \\
\text { humus } \\
\text { horizon, } \\
\mathrm{cm}\end{array}$ & $\begin{array}{c}\text { Humus, } \\
\%\end{array}$ & $\begin{array}{c}\text { Salt } \\
\text { extract pH }\end{array}$ & $\begin{array}{c}\text { Physical } \\
\text { clay, \% }\end{array}$ & $\begin{array}{c}\text { Mobile } \\
\text { phosphorus, } \\
\mathrm{mg} / \mathrm{kg} \text { soil }\end{array}$ & $\begin{array}{c}\text { Exchange } \\
\text { potassium, } \\
\mathrm{mg} / \mathrm{kg} \\
\text { soil }\end{array}$ & $\begin{array}{c}\text { Total } \\
\text { absorbed } \\
\text { bases, } \\
\mathrm{mmol} / \\
100 \mathrm{~g} \text { soil }\end{array}$ & $\begin{array}{c}\text { hydrolytic } \\
\text { acidity } \\
\mathrm{mg-eq} / \\
100 \text { g soil }\end{array}$ \\
\hline 1 & 1 & $5-15$ & & 4.3 & 7.4 & & & & & \\
\hline 2 & 5 & $20-30$ & 34 & 1.7 & 6.0 & & 82.0 & 35.0 & 9.5 & \\
\hline & & $40-50$ & & 0.9 & & & & & & \\
\hline & & $60-70$ & & 0.6 & & & & & & \\
\hline 4 & 3 & $5-15$ & 18 & 1.0 & 5.5 & & 75.0 & 50.0 & 9.9 & 2.0 \\
\hline & & $20-30$ & & 0.7 & & & & & & \\
\hline 6 & 4 & $10-20$ & 38 & 2.4 & 5.9 & & 60.0 & 60.0 & 30.5 & 1.5 \\
\hline & & $40-50$ & & 0.7 & & & & & & \\
\hline 9 & 2 & $10-20$ & 33 & 1.4 & 5.9 & & 47.5 & 50.0 & 38.7 & \\
\hline & & $45-55$ & & 0.7 & & & & & & \\
\hline 11 & 6 & $10-20$ & 40 & 4.2 & 5.8 & & 131.5 & 120.0 & 35.0 & \\
\hline & & $40-50$ & & 0.4 & & & & & & \\
\hline 12 & 9 & $20-30$ & 29 & 2.7 & 6.5 & & 37.5 & 60.0 & 52.7 & \\
\hline & & $40-50$ & & 2.2 & & & & & & \\
\hline 14 & 7 & $5-15$ & 20 & 5.5 & 6.1 & & 47.5 & 32.0 & 29.3 & \\
\hline & & $20-30$ & & 1.0 & & & & & & \\
\hline
\end{tabular}

Source: authors 


\begin{tabular}{|c|c|c|c|c|c|c|}
\hline \multirow[t]{2}{*}{ Sample depth, cm } & \multirow[t]{2}{*}{ Humus \% } & \multicolumn{3}{|c|}{ Gross forms, $\%$} & \multicolumn{2}{|c|}{$\begin{array}{c}\text { Active forms, } \\
\mathrm{mg} / 100 \mathrm{~g} \text { (according to Kirsanov) }\end{array}$} \\
\hline & & $\mathrm{N}$ & $\mathrm{P}$ & $\mathrm{K}$ & $\mathrm{P}_{2} \mathrm{O}_{5}$ & $\mathrm{~K}_{2} \mathrm{O}$ \\
\hline \multicolumn{7}{|c|}{ Sandy loam. Section 1-86. Seedbed. } \\
\hline \multicolumn{7}{|c|}{ Angasyak breeding nursery. Common pine (Pinus sylvestris), 2Y. } \\
\hline $0-26$ & 2.7 & 0.25 & 0.12 & 0.3 & 4.6 & 14 \\
\hline $26-36$ & 1.6 & 0.125 & 0.075 & 0.88 & 8 & 16.5 \\
\hline $45-55$ & 0.6 & 0.07 & 0.15 & 0.3 & 4 & 6.6 \\
\hline \multicolumn{7}{|c|}{ Sandy loam. Section 6-86. Gramineous pinery. } \\
\hline \multicolumn{7}{|c|}{ Angasyak forestry, sq. 41. Siberian spruce (Picea obovata), 3Y. } \\
\hline $2-12$ & 4.1 & 0.780 & 0.11 & 0.4 & 5.2 & 8.0 \\
\hline $12-25$ & 0.5 & 0.125 & 0.10 & 0.4 & 8.65 & 6.3 \\
\hline $26-36$ & 0.4 & 0.125 & 0.065 & 0.5 & 12.0 & 11.0 \\
\hline
\end{tabular}

Source: authors

Table 3: Humus content, gross and active forms of nitrogen, phosphorus, and potassium on forest lands.

Since the conditions of soil formation are identical, the main agrochemical indicators on different-purpose lands do not differ much. However, agricultural land is more susceptible to the anthropogenic effect. Approximately the same indicators show that agriculture in this area is done at the proper level without disrupting the technological process.

The information obtained from the 1960s and 1970s, which is commonly used, is no longer relevant to represent the reality of the current soil condition (Kumar and Geeta, 2009). Due to various changes in land use, crop management, intensive cultivation, combined with unbalanced fertilization, some fertile soils in the past have reached the status of degraded or unproductive land. Therefore, the current focus is on developing modeling approaches using new GIS and remote sensing methods as a possible option for reducing the cost factor. A holistic approach based on GIS has proved effective in converting useful subjective, qualitative, and categorical information into objective and quantitative one that serves modern requirements to update soil information.

The soil and agrochemical survey of the Shchelkovo training and experimental forestry nursery territory was carried out using geoinformation technologies (Martynenko et al., 2019). The purpose of this work was to conduct a soil survey of arable sod-podzolic medium - or light-loam soils of the forest nursery territory, as well as to assess the contamination of the production areas with weeds. The peculiarity of this study was collecting, systematizing, and processing the information focused on the use of modern geoinformation systems. The survey points were selected in agreement with the nursery administration and specified following the actual satellite images. The geographical reference of test points was carried out using global positioning technologies (GPS, GLONASS) based on the NextGIS mobile application (Android OS). The photo fixation of nursery fields was carried out using geotagging technologies, which allow implementing the received graphic information directly into the geographic information system (GIS). Soil samples collected in the field were analyzed in the soil laboratory to determine the main indicators of soil fertility. Based on the obtained data, the cartograms were developed using GIS, which provide the information about the original nutrient content of nursery fields, as well as about the most important indicators that characterize the soil-absorbing complex (soil acidity, degree of base saturation, etc.). The study of weed infestation allowed us to develop a thematic map that reflects the weed distribution in the nursery fields. All the collected information was combined into a comprehensive geo-information system designed on the basis of the quantum GIS shell. As a result, the developed GIS will contribute to the operational monitoring of soil fertility and provide information support for the agricultural equipment used in the nursery to grow planting material.

The availability of sufficient and accurate spatial data related to land resources is the basis for the sustainable development of agricultural production. The work was carried out to use remote sensing and geostatistical analysis tools within the geographic information system (GIS) to map the land potential and crop production for an area in the Qattara Depression, the Western desert 
of Egypt. The depression is located to the East of the Qattara Depression between $30^{\circ} 10^{\prime} 4^{\prime \prime}-30^{\circ}$ $20^{\prime} 57^{\prime \prime} \mathrm{N}$ latitude and $28^{\circ} 32^{\prime} 26^{\prime \prime}-28^{\circ} 52^{\prime} 10^{\prime \prime} \mathrm{E}$ longitude, covering $630 \mathrm{~km}^{2}$ (63,000 ha) (Abbas et al., 2020). Thirty-seven soil profiles were dug up to $150 \mathrm{~cm}$. Soil samples were collected from different horizons and analyzed for their main properties. The Applied System for Land Evaluation (ASLE) was used through the appropriate software to assess land potential and suitability. Landforms include sand slabs, dunes, depressions, sabkha (Arabic term for landforms formed when saline soils dry out in deserts and semi-deserts), and water bodies. $74.69 \%$ of soils are "poor" (C4), $0.47 \%$ are "good" (C2), $11.68 \%$ are "satisfactory" (C3), $11.12 \%$ are "very bad" (C5), and $0.47 \%$ are "nonagricultural" (C6). The main limiting factors are the soil structure, its salinity, and alkalinity. Suitability classes (including 22 crops) can be divided into highly suitable (S1), suitable (S2), moderately suitable (S3), marginally suitable (S4), currently not suitable (N1), and potentially not suitable (N2) for 22 crops. The most recommended crops are date palm (Phoenix dactylifera) and tomatoes. The studied soils require precise management methods to be used for agriculture in the future (Abbas et al., 2020).

Digital soil mapping involves the creation and placement of spatial soil information obtained using field and laboratory observation methods in combination with spatial and non-spatial indicators. These maps represent the soil characteristics and parameters in digital form. The method for obtaining a digital soil map is computer-integrated, based on GIS software and agricultural knowledge. In order to compile a digital map of Herat soil classification, a cluster of various relief features (slope, slope exposure, micro-relief) obtained from the DEM (digital elevation model) of Herat province with a geological map of the specified territory was used in the study. As a result of the research, a digital soil map has been obtained showing different soils of Herat province, which are highlighted in different colours on the map, and areas with the same colours have similar soil properties. The work has made a significant contribution to solving the problem of the insufficiency of current quantitative and accurate soil data. Thus, the results obtained can be used in solving social, economic, and environmental issues.

The development of forest soil digital maps is a necessity both worldwide and at the national level. Currently, there are many maps of this kind and geographic information systems (Dincă et al., 2014). One of the examples is SIGSTAR 200, a system implemented by the Pedological Research Institute, ICPA Bucharest. Soil variants were grouped into a series of 32 soil types and subtypes by the Romanian soil classification system (SRTS 2003). Changes were introduced to the map using the pedological database of the Forest Research and Management Institute (ICAS) (2,665 soil profiles have been made over the past five years within the National forest inventory) and Rumanian geology and ecosystem GIS maps. Overlapping the boundaries of the forest areas and production units on the soil map allows the geographical soil distribution within the administrative boundaries of the forest fund. The information from this map, which includes various databases, can be used in forestry activities, in the preparation of different national or international projects, in the creation of other maps and databases, as well as in other economic or scientific activities.

A natural landscape map (of administrative districts) of the Republic of Sakha (Yakutia) was compiled on a scale of 1:2,500,000. GIS tools were used to link thematic cartographic documents to a topographic map containing contour lines, relief, and a hydrographic network (Kolejka, 2018). Data from Google Earth played a significant role in the subsequent mapping stages: 2D and 3D images were used to identify floodplains. The glacial landform units of the foothill territories and the main types of geological and geomorphological units were determined using both published data sources and Google Earth images. A map of natural vegetation has been compiled, taking into account the humidity regime and vertical zoning of the climate and soils. Digital cartographic layers in GIS were gradually combined into a synthetic natural landscape map, and the identified natural and landscape units were also included in the regional classification of Siberian landscapes. It is established that the hierarchical system of natural landscapes differentiates three classification levels: high (landscapes are distinguished by their geographical location into lowland and high-altitude landscapes), intermediate (landscape differentiation by the genesis and relief division in the corresponding climatic zone) and low (natural landscapes are determined by the vegetation covering the soil type that has developed on this geological substrate). 
In Russia, it is long overdue to create a world-class soil attribute (profile) information database, which should become the basis for creating a system for monitoring the soil state and developing measures for their protection and rational land use. There is a need for a unified system for collecting and storing the information about soils, which would be open to the general use (Kolesnikova et al., 2010). Kolesnikova and co-authors have studied the concept and methodology of creating a soil-geographical database of Russia (SGDB) and developed the proposals for the structure and content of the soil attribute database, which is based on the concept of representative soil profiles. A list of classifiers has been compiled for data presentation formats in SGDB based on the existing soil morphology concepts, classifiers that characterize main physical and chemical soil properties.

The scientists from Volgograd State University study a landscape program that involves the formation of a land-use system aimed at connecting the protective forest belts with the geomorphological elements of the catchment area, relief, and dissimilarity of agricultural territories adapted to the dynamically balanced state of matter and energy within the landscape. This approach contributes to the development of a farming land assessment system through forest reclamation. This is due to the transformation (restructuring) of the qualitative and quantitative characteristics of energy and mass exchange. Consequently, radiation, thermal, soil, hydrophysical, and hydrodynamic processes also change. Thus, the area adjacent to the protective forest belt is a zone of the deterministic processes, while further away from the forest belt, the space is open for changing all characteristics. When assessing the land geoecology, the agroforestry landscape was considered as an agricultural landscape modification, which is formed and operated under the influence of the protective forest belts. The optimal organization of the irrigated agriculture should take into account the landscape heterogeneity of the territory. That was done through the interpretation of the space photos. According to the bioclimatic zonal indications, the agricultural landscape types of dry steppe and desert steppe were determined. Irrigated soils of the Volgograd region are located mainly in drysteppe agro-forest landscapes on dark chestnut and chestnut soils within the natural reclamation areas of the Volga and Ergeninsky hills and partially in the trans-Volga delta plain; in semi-desert agro-forest landscapes on light chestnut soils within the trans-Volga delta plain and the Sarpinsky lowland. The favorable hydrogeological and land reclamation situation on the territory of the Southern Volga upland makes it possible to revive the irrigation in the Volgograd region and thereby increase the productivity and sustainability of the agricultural production at a higher scientific level using a geo-ecological approach (Ruleva and Rulev, 2015).

Geospatial analysis of the selected territory (Western Turkey, Izmir region) with the combined use of Google Earth, Landsat TM satellite images, and Erdas Imagine GIS programs is presented in the article by Turkish scientists. Advantages of using satellite images (multispectral images of Landsat TM and ETM +, Google Earth) in combination with GIS software for geospatial analysis tasks that are often solved in Higher education courses in geography and Earth sciences. This work provides an example of a successful landscape study. Studying the distribution of various types of the earth's surface, modeled using Landsat TM and Google Earth, allows you to analyze the dynamics of landscape changes. The work has also demonstrated the effective use of the Google Earth web service for thematic mapping. Image processing technologies were used to classify the images using the methods of the available Erdas Imagine software modules. The Google Earth web service was used to check and validate the mapping results using the Google Earth binding module (Lemenkova, 2015).

However, the productive forces of soil resources are gradually being depleted on the planet. In many agricultural areas of Taiwan, the crop yields were destroyed as a result of severe soil erosion. Nitrogen fertilizers and fossil fuels are usually scarce, which leads to both increased agricultural production costs and increased geopolitical conflicts. The recent increase in demand for phosphorus has led to a sharp rise in the phosphate ore cost - from $\$ 80$ per ton in 2000 to $\$ 450$ per ton in 2015. Prices have fluctuated since then, and now it is about $\$ 700$ per ton. In addition to rising costs, mining is also a difficult problem. According to rough data, Morocco has the world's largest geological phosphorus reserves, but most of them are located in the disputed areas.

On the other hand, there are only about $2 \%$ of the world's phosphate ore reserves. According 
to current production rates, the richest phosphorus sources in the United States will be depleted in 20 years, leading to the increased dependence on phosphorus imports, which will support the demand from agriculture and industry. Global warming, on the other hand, accelerates the release of microbial greenhouse gases (GHGs) in soils and plays a crucial role in ongoing climate change. Soils and forests are becoming the key factors for human survival and development. This global development trend should be a guideline for Taiwan's future land and forest development policy (Lu, 2017).

Machine learning methods are widely used to create digital soil maps. The map accuracy is partly determined by the measurement number and spatial location used to calibrate the machine learning model (Wadoux et al., 2019). However, determining the optimal sampling scheme for mapping using machine learning methods has not yet been considered in detail in digital soil mapping studies. The optimization of the sample design for soil mapping was investigated. The design is optimized using the spatial simulation annealing by minimizing the standard error of prediction (SEP). This approach has been applied in compiling the soil maps for Europe using subsamples of the Lucas dataset. Optimized subsamples are used as input data for the machine learning model, using a broad set of readily available ecological data.

Taking into account the above, the method of creating the digital soil maps for the entire territory, including those occupied by agricultural production and forest plantations, will allow for more efficient use of land resources.

\section{Conclusion}

The introduction of GIS technologies, along with the new methods of information collection, makes it possible to significantly simplify and automate the process of studying and monitoring land resources throughout the entire work chain. The digital information is easily editable and stores data without any time limits, being a matrix for obtaining the high-quality cartographic products of any content and design. The main problem is a certain complexity of the process of getting digital material, which is easily eliminated when improving the work methodology.

At this stage, the active GIS implementation in the process of managing land monitoring is constrained by several objective factors. First of all, this is a lack of digital material on land resources. GIS development in the Republic of Bashkortostan does not have a very long history, and a few organizations are engaged in maintaining digital spatial information at the national and regional levels.

At the moment, the primary task in creating a GIS is to accumulate the digital data bank, develop a unified methodology and requirements for obtaining digital information. Only after the material has been collected and consolidated over a sufficiently large area, all the features of geo-information systems can be used.

The work in this direction is necessary to provide users with further operational information, primarily rural producers. The world experience shows that information technologies are highly effective in the agricultural sector.

Corresponding authors

Marat Ishbulatov, Candidate of Agricultural Sciences

Department of Real Estate Cadastre and Geodesy, Federal State Budgetary Educational Establishment

of Higher Education "Bashkir State Agrarian University", 50-letia Octyabrya Str., 34, Ufa, 450001, Russia

Phone:+79373107807,E-mail: ishbulatovma@rambler.ru

\section{References}

[1] Abbas, H., Abuzaid, A. and Yaccub, R. (2020) "Land evaluation of east Qattara Depression, Egypt using remote sensing and GIS", $5^{\text {th }}$ International Conference on Biotechnology Applications in Agriculture (ICBAA), Benha University, 8-11 April 2020, Egypt.

[2] Allbed, A., Kumar, L. and Sinha, P. (2018) "Soil salinity and vegetation cover change detection from multi-temporal remotely sensed imagery in Al Hassa Oasis in Saudi Arabia", Geocarto International, Vol. 33, No. 8, pp. 830-846. E-ISSN 1752-0762, ISSN 1010-6049. DOI 10.1080/10106049.2017.1303090. 
[3] Chalise, D., Kumar, L., Shriwastav, C.P. and Lamichhane, S. (2018) "Spatial assessment of soil erosion in a hilly watershedof Western Nepal", Environmental Earth Sciences, Vol. 77. E-ISSN 1866-6299, ISSN 1866-6280. DOI 10.1007/s12665-018-7842-3.

[4] Chhogyel, N. and Kumar, L. (2018) "Climate change and potential impacts on agriculture in Bhutan: a discussion of pertinent issues", Agriculture \& Food Security, Vol. 7. ISSN 2048-7010. DOI 10.1186/s40066-018-0229-6.

[5] Churagulova, Z. S. (2003) "Soils of forest nurseries of the southern Urals: properties, changes, optimization", TISSOT, Moscow.

[6] Curebal, I., Efe, R., Soykan, A. and Sonmez, S. (2015) "Impacts of anthropogenic factors on land degradation during the anthropocene in Turkey", Journal of Environmental Biology, Vol. 36, No. 1, pp. 51-58. ISSN 02548704.

[7] Dincă, L., Sparchez, G. and Dincă, M. (2014) "Romanian's forest soils gis map and database and their ecological implications", Carpathian Journal of Earth and Environmental Sciences, Vol. 9, pp. 133-142.E-ISSN 1844489X, ISSN 18424090.

[8] FAO (2011) "FAO in the 21 ${ }^{\text {st }}$ Century: Ensuring Food Security in a Changing World", Rome, Food and Agriculture Organization of the United Nations.

[9] Gosa, C. I. and Mateoc-Sirb, N. (2014) "Agricultural lands bonitation and estimation of crop production in Almajului Valley, Caras-Severin County", 14 $4^{\text {th }}$ International Multidisciplinary Scientific GeoConference SGEM 2014, Vol. 2, Book 3, pp. 11-14. ISBN 978-619-7105-14-8. ISSN 1314-2704. DOI 10.5593/SGEM2014/B32/S13.002

[10] Ishbulatov, M. G., Miftakhov, I. R. and Mindibaev, R. A. (2018a) "Creating a digital soil map of agricultural lands in the Republic of Bashkortostan Col.: cadastral and ecological and landscape support of land management in modern conditions", Materials of the international scientific and practical conference of the faculty of land management and cadastre of VSAU, pp. 100-103.

[11] Ishbulatov, M. G., Mindibaev, R. A., Safin, K. M., Baikov, A. G., Miftakhov, I. R., Baygildina, G., Zamanova, N., Khisamov, R. and Yagafarov, R. G. (2018b) "The Bioenergetic Approach to Evaluation of Arable Land Fertility", Journal of Engineering and Applied Sciences, Vol. 13, pp. 8353-8359. ISSN 1816-949X.

[12] Jia, G., Zhang, L., Zhu, L., Xu, R., Liang, D., Xu, X. and Bao, T. (2019) "Digital Earth for Climate Change Research", In Manual of Digital Earth, pp. 473-494. ISBN 978-981-329-915-3. DOI 10.1007/978-981-32-9915-3_14.

[13] Kalinin, A. G. (2015) "Data processing by mathematical statistics methods", Monograph. TBI of SUCC, Chita.

[14] Karmakar, R., Das, I., Dutta, D. and Rakshit, A. (2016) "Potential Effects of Climate Change on Soil Properties: A Review", Science International, Vol. 4, pp. 51-73. ISSN 1013-5316.

[15] Kayet, N. and Pathak, K. (2015) "Remote Sensing and GIS-Based Land use/Land cover Change Detection Mapping in Saranda Forest, Jharkhand, India", International Research Journal of Earth Sciences, Vol. 3, pp. 2321-2527. ISSN 14373254.

[16] Kimaro, J. and Lulandala, L. (2013) "Human Influences on Tree Diversity and Composition of a Coastal Forest Ecosystem: The Case of Ngumburuni Forest Reserve, Rufiji, Tanzania", International Journal of Forestry Research, Vol. 6, No. 2. E-ISSN 1687-9376, ISSN 1687-9368. DOI 10.1155/2013/305874.

[17] Kolejka, J. (2018) "Landscape Mapping Using GIS and Google Earth Data", Geography and Natural Resources, Vol. 39, pp. 254-260. E-ISSN 1875-371X, ISSN 1875-3728. DOI $10.1134 / \mathrm{S} 1875372818030095$.

[18] Kolesnikova, V., Alyabina, I., Vorob'eva, L., Molchanov, E., Shoba, S. and Rozhkov, V. (2010) “Soil attribute database of Russia", Eurasian Soil Science, Vol. 43, pp. 839-847. E-ISSN 1556-195X, ISSN 1064-2293. DOI 10.1134/S1064229310080016. 
[19] Kumar, P. S. and Geetha, S. A. (2009) "A Holistic GIS-based Approach for Thematic Extraction of the Soil Erosion Estimates Using Predictors as a Function of Climate, Land Cover, Relief, Soil, and Topography", Asian Journal of Water, Environment and Pollution, Vol. 6, No. 3, pp. 73-78. E-ISSN 1875-8568, ISSN 0972-9860.

[20] Lemenkova, P. (2015) "Google Earth web service as a support for GIS mapping in geospatial research at universities", Web-Technologies in the Educational Space. Problems, Approaches, Perspectives, pp. 24. DOI 10.6084/m9.figshare.7211798. (In Russian).

[21] López-García, E., Torres-Trejo, E., López-Reyes, L., Flores-Domínguez, Á., Peña Moreno, R. and Olguín, J. F. (2019) "Estimation of soil erosion using USLE and GIS in the locality of Tzicatlacoyan, Puebla, México", Soil and Water Research, Vol. 15, No. 1, pp. 9-17. E-ISSN 1178-6221. DOI 10.17221/165/2018-SWR.

[22] Lu, S.-M. (2017) "Soil and Forest: The Key Factors for Human Survival", Journal of Sustainable Development, Vol. 10, pp. 105-119. I-SSN 1913-9071, ISSN 1913-9063. DOI 10.5539/jsd.v10n3p105.

[23] Lucà, F., Buttafuoco, G. and Terranova, O. (2018) "GIS and Soil", In Comprehensive Geographic Information Systems, pp. 37-50. ISBN 978-0-12-804793-4. DOI 10.1016/B978-0-12-409548-9.09634-2.

[24] Varma M. K. R., Jyothi, S., Varma, S. A. K. and Varma, S. V. (2011) "Construction of Spatial Dataset from Remote Sensing using GIS for Deforestation Study General Terms", International Journal of Computer Applications, Vol. 31, No. 10, pp. 26-32. ISSN 0975-8887.

[25] Martynenko, O., Karminov, V., Yugaj, E., Mutygullin, I. and Ontikov, P. (2019) "The use of GIS for agrochemical soil characteristics and weed infestation of Grebnevskiy nursery of Shchelkovskiy teaching and experimental forestry", Dokuchaev Soil Bulletin, Vol. 99, pp. 5-20. E-ISSN 2312-4202, ISSN 0136-1694. DOI 10.19047/0136-1694-2019-99-5-20. (in Russian).

[26] Nguemzei, C., Tematio, P., Yemefack, M., Tsozué, D. and Silatsa, Fs. (2020) "Soil quality and soil fertility status in major soil groups at the Tombel area, South-West Cameroon", Heliyon, Vol. 6, No. 2. E-ISSN 2405-8440. DOI 10.1016/j.heliyon.2020.e03432.

[27] Pendzhiev, A. M. (2013) "Ecological problems of desert development: migration, pasture improvement, and global land degradation", Alternative Energy and Ecology, Vol. 14, No. 136, pp. 89-107. ISSN 2348-5159.

[28] Ramazanoglu, E., Gundogan, R. and Saltali, K. (2019) "Soil formation, Classification, and Mapping of Soils of Catchment of TopçuCreek", International Conference on Agriculture, Food, Veterinary and Pharmacy Sciences, pp. 1122-1127.

[29] Ruleva, O. and Rulev, A. (2015) "Landscape Planning of Forest Amelioration on Irrigated Soils", Geofrafia i geoinformatika, Vol.11., pp. 74-80. ISSN 2519-4437. DOI 10.15688/jvolsu11.2015.2.9. (in Russian)

[30] Shapovalov, D. A., Rukhovich, D. I., Kulyanitsa, A. L., Kalinina, N. V., Koroleva, P. V. (2018) "Elements of soil and land cover mapping in the cadastre system of the Russian federation," International Multidisciplinary Scientific GeoConference-SGEM.

[31] Sultanova, R. R., Gabdrahimov, K. M., Khayretdinov, A. F., Konashova, S. I., Konovalov, V. F., Blonskaya, L. N., Sabirzyanov, I. G., Martynova, M. V., Isyanyulova, R. R. and Gabdelkhakov, A. K. (2018) "Evaluation of Ecological Potential of Forests", Journal of Engineering and Applied Sciences, Vol. 13, pp. 6590-6596. E-ISSN 1816949X, ISSN 18187803.

[32] Techen, A. K., Helming, K., Brüggemann, N., Veldkamp, E., Reinhold-Hurek, B., Lorenz, M., Bartke, S., Heinrich, U., Amelung, W., Augustin, K., Boy, J., Corre, M., Duttman, R., Gebbers, R., Gentsch, N., Grosch, R., Guggenberger, G., Kern, J., Kiese, R. and Vogel, H.-J. (2020) "Chapter four - Soil research challenges in response to emerging agricultural soil management practices", Advances in Agronomy, in press. Vol 164, pp. 179-240. DOI 10.1016/bs.agron.2020.01.002. 
[33] Uskov, V. N. and Bulat, P. V. (2014) "Shock and detonation wave in terms of view of the theory of interaction gasdynamic discontinuities", Life Science Journal, Vol. 11, No. 8, pp. 307-310. ISSN 10978135.

[34] Várallyay, G. (2010) "The impact of climate change on soils and their water management", Agronomy Research, Vol. 8, No. 2, pp. 385-396. ISSN 1406894X.

[35] Wadoux, A., Brus, D. and Heuvelink, G. (2019) "Sampling design optimization for soil mapping with random forest”, Geoderma, Vol. 355. ISSN 0016-7061. DOI 10.1016/j.geoderma.2019.113913.

[36] Zaripova, G. K. Kaipov, Y. Z., Safin, H. M., Mindibaev, R. A., Nugumanov, A. Kh. and Chanyshev, I. O. (2009) "Main technological methods for improving the soil fertility and effective use of degraded lands in Bashkortostan (recommendations)", Ufa, Print World, 44 p. ISBN 5961300757. 